\title{
Biocommunication and Bioeconomy in Rio de Janeiro
}

\author{
Rosane da Conceição Pereira ${ }^{1,2}$ \\ ${ }^{1}$ Department of Social Communication, Salgado de Oliveira University, Niterói, Brazil \\ ${ }^{2}$ Department of Social Communication, Eteab/Faetec, Rio de Janeiro, Brazil
}

Email address:

rosadosol@yahoo.com.br, rosane.da.conceicao.pereira@pq.cnpq.br

\section{To cite this article:}

Rosane da Conceição Pereira. Biocommunication and Bioeconomy in Rio de Janeiro. Arabic Language, Literature \& Culture.

Vol. 5, No. 2, 2020, pp. 9-13. doi: 10.11648/j.allc.20200502.11

Received: January 28, 2020; Accepted: February 28, 2020; Published: June 28, 2020

\begin{abstract}
It's a project proposal for the National Science and Technology Week CNPq - SNCT 2019 [\# snct2019]. It's based on the teaching of visual communication campaigns on Elementary School I to High School Environmental Environmental Education Campaigns in public schools, ranging from selective waste collection to Demarketing or conscious consumption of products of natural origin such as water, gas and light; the creation of bioproducts derived from the refinery oil recycling in handcrafted soap, recycled marché or seed paper, battery collectors and batteries with pet bottles; it involves the reuse of gutter water for the garden and cleaning of the school, and the reuse of paper for scratch pads and murals, among other reuses. It suggests apprenticeship schools or cells of Bioeconomics, Diversity and Wealth actions for Sustainable Development. Transdisciplinary and interdisciplinary practices in theater, arts, sciences, languages and digital environmental communication will be promoted, combining artistic and academic knowledge with artistic, professional and cultural activities through the use of digital and audiovisual resources, in the activities developed in the teaching units and at ETEAB / FAETEC. This study depends on approval by CNPq evaluation committee and it does not intend to anticipate results of work proposal for SNCT 2019.
\end{abstract}

Keywords: Biocommunication, Bioeconomy, Rio de Janeiro

\section{Introduction to Fundamental Concepts}

The article deals with the diffusion of knowledge through teaching the creative planning of advertising pieces on Socioenvironmental Responsibility, that is, on awareness and practices of respect for social and environmental life [6] in schools of the basic and medium-technical-professional levels of public network FAETEC, in manual, printed or audiovisual format such as posters, banners, collages, photomontages, videos and other pieces made on paper or by smartphones or cameras.

The theme is Bioeconomics or Sustainable Economy [2], engaging students from different social realities in terms of linguistic, cultural, biological, ethnic, religious diversity, at the Fundamental I, II and Medium-Technical levels, in public education in Rio de Janeiro, belonging to social classes between A and D [3] of both sexes, including Afro-descendants, coming from communities, from the urban perimeter and from the interior of the state [15]. Thus promoting the Social Wealth of the participating municipalities. Two schools in Campos dos Goytacazes, one in Marechal Hermes, São Cristóvão, Quintino Bocaiúva, Niterói, Saquarema and Volta Redonda. Has the proposal of contribution of Education and Communication for the optimization of the purchasing power of citizens in training with savings and use of goods learned at school and taken home, rethinking social values and responsible habits for life, based on human and cultural resources.

"Bioeconomics is the result of an innovative revolution in the area of biological sciences related to the invention, development and use of biological products and processes in the areas of industrial biotechnology, human health and agricultural and livestock productivity. According to the Action Plan on Science, Technology and Innovation in Bioeconomics [PACTI Bioeconomics], the guiding document of the MCTIC for the scientific and technological development of Bioeconomics in the Country, it can be defined as:

The set of economic activities based on the sustainable and innovative use of renewable biological resources [biomass], replacing fossil raw materials, for the production of food, feed, materials, chemicals, fuels and energy produced through biological processes, chemical, thermochemical or physical, 
promoting health, sustainable development, national growth and the well-being of the population." [8].

The concept of Bioeconomy refers to ideas, practices and products that underpin sustainable development in its relationship with human and biological diversity [13], added to the social and cultural wealth [14] of young citizens and students in our state [4], linking all these products to communication [5] on the social network Facebook of the "Agência Laboratório NeoAB Marketing e Comunicação".

Demarketing is a "term coined during the energy scarcity of the 1970s and 1980s, when advertising was used to cool demand for products" [1], which consists of the economy and conscious use of scarce and industrialized resources that are potentially harmful to the environment and to social, local and global health.

According to the Ministry of Science, Technology, Innovations and Communications [7], Bioeconomy "arises as a result of a revolution of innovations based on the biological sciences, which culminate in the development of more sustainable products, processes and services" [7] in several social institutions, such as the institutions of education, health, food, energy and water, for example.

Bioproducts [8], therefore, are both natural and organic, and those derived from demarketing actions on discarded industrialized products, that is, the reuse of rainwater for irrigation, drinking water for cleaning, packaging for gardening, making selective collection boxes, recycled paper and others.

With regard to Biocommunication, according to the magazine "Communicative \& Integrative Biology", biological organisms are "systems integrated via bio-communication. This includes animals, plants and microbial communication and signaling, cognition, consciousness, evolution, ecology and behavioral ecology, as well as biophysics and neuroethology" [11].

One can relate the bioeconomy as a more comprehensive area of Human and Social Sciences that includes others, such as Social Communication and Advertising, with demarketing as an action related to conscious consumption, sustainable economy, social and environmental responsibility for maintenance and improving life or living things [6]. A possible analysis of the effects of meaning in the historical and ideological field or discourse [10] of demarketing, in its relation to the bioeconomy, biocommunication and demarketing are campaigns of socio-environmental responsibility or awareness of environmental and social life, the that occurs in educational institutions and companies.

Within the methodology of the project proposal, it is planned to return to schools apprentices in the development of a campaign or advertising pieces of social and environmental responsibility, such as posters and posts on social networks about making bioproducts such as recycled paper, containers for selective collection, gardens and vertical gardens with packaging, rain water and drinking fountain for cleaning the school, among other actions. Subsequently, through a second visit and sending by e-mail, photographs and / or footage from the environmental education and Demarketing Campaigns,
Bioproducts and Reuse actions developed by posters, banners, collages will be obtained. Teachers and students from these interested institutions will be able to exhibit their productions at the "Flavors Week" [Technical Week] of the State Technical School Adolpho Bloch of the Technical School Support Foundation - ETEAB / FAETEC [executor of the Project]. Extra-wall activities are planned in public places with a large flow of people, such as open institutional activities and widely publicized on the social network Facebook of the "Agência Laboratório NeoAB Marketing e Comunicação", of the Technical Course in Advertising of ETEAB-FAETEC executing the Project and on the website official SNCT 2019 or other devices if requested by CNPq and / or MCTIC.

The methodology consists of interinstitutional collaboration. Collaborators will support the project coordinator by guiding teachers and internal and external audiences about the proposal; in addition to the preparation, monitoring and analysis of scientific-cultural events and transdisciplinary / interdisciplinary actions to disseminate the sciences Bioeconomics and Biocommunication [12], during the Sabores Mix Technical Week and the National Science and Technology Week, which will take place on ETEAB-FAETEC and will be shown on the school's social and external networks. The Coordinara will guide collaborating professors of ETEAB-FAETEC and external [CEFET, CEP / FDC / DECEx / DETMil, SENAC, UFF, UFRJ, UFRRJ, UFSB, ESPM, UNIVERSO and UNIRIO]. It will involve the general public, elementary education I and II, vocational high school / technician and public superior, interested in Bioeconomics and Socio-environmental Campaigns or Demarketing, Reuses and Bioproducts for Sustainability, Diversity and Social Wealth. It aims to reach different, special social segments, girls / women of African descent and communities.

The proposal has the general objective of teaching what they are and how to communicate the proposed social and environmental responsibility campaigns of EEEFs and ETEs Campos dos Goytacazes, Marechal Hermes, Niterói, Quintino Bocaiuva, São Cristóvão, Saquarema and Volta Redonda. It has specific objectives to develop scientific-cultural and transdisciplinary / interdisciplinary events to disseminate the sciences Bioeconomy and Biocommunication, in the SNCT ETEAB-FAETEC there will be Exhibition / photos; Open doors; Lecture; Workshops; Videos; Fair / Exhibition; and Scientific communication on Facebook / Instagram, Youtube and Twitter networks with the official SNCT hashtag.

\section{Issue History}

\subsection{The Theme at the National Science and Technology Week [SNCT]}

During SNCT 2018, a survey was carried out on the "Panel of the Digital Generation of Secondary-Technical Education in the FAETEC Network" in five units of FAETEC's technical and vocational secondary education in different municipalities in Rio de Janeiro, such as Angra dos Reis, Barra do Piraí, Campos dos Goytacazes, Niterói and São Cristóvão, with 
theories and techniques of quantitative and qualitative research and the free Google form, in order to Research the Profile of the young student in Brazilian public education from sixteen to eighteen years old and above that age with the Discourse analysis on the language of social networks suggested lines and images in posts. With workshops, open day visit and intern activity for a day; seminar or cycle of lectures / round table; show of videos / photos and scientific communication events in other media at the executing ETEAB-FAETEC, shown in the collaborating educational institutions, during SNCT 2018. The collaborators belong to different institutions CEFET-RJ, CEP / FDC / DECEx / DETMil, SENAC RJ, UFF, UFRJ, UFRRJ, UFSB, UNILASALLE, UNIVERSO and UNIRIO, in the public and private spheres, of medium-technical and professional levels, with repercussions in different parts of the country and of international renown, accessible through their websites and communication devices. The promotional material about activities and events produced in the 2018 proposal is available on the SNCT website and on the Facebook of the laboratory agency NeoAB Marketing e Comunicação of the executing headquarters ETEAB-FAETEC.

\subsection{Methodology About Educational Strategies}

With regard to the Strategy for the dissemination and popularization of the sciences Bioeconomics or Sustainable Economics and Biocommunication or campaigns for socioenvironmental responsibility, demarketing or conscious consumption and bioproducts or recycling, reuse and natural / organic products in schools. It involves the production of educational tools for the dissemination and popularization of scientific knowledge for the teaching of social and environmental responsibility campaigns in the schools of the FAETEC network referred to.

\section{Communication and Possible Strategies}

As for the dissemination of the knowledge acquired in the suggested schools and in the proposed events and activities, it will be communicated on social media and with unpaid resources, such as cell phones of creative students in teaching units, for didactic purposes and portals that make it possible to create open applications. The concept of demarketing or conscious consumption and bioproducts, which are recycled, reused and natural / organic in these places, will be addressed: tools such as Social Media Pages or Canvas on Facebook or Google, free to use, accessible even after SNCT 2019.

\section{Collaborating Institutions in Results and Discussion}

Therefore, the proposal includes higher education institutions for collaborating teachers, such as Rio de Janeiro-RJ, Niterói-RJ, Itabuna-BA, Seropédica-RJ, Niterói and São Gonçalo - RJ, Nova Iguaçu-RJ, Niterói-RJ, Flamengo -RJ, Centro-RJ, Urca-RJ, São Domingos-Niterói-RJ and Leme-RJ, in addition to ETEs and EEEFs / by the executor ETEAB-FAETEC / Advertising / Audio and Video Production / Sciences / Arts / Languages, UFRJ / MN, UFF / Letras / Other elementary and technical courses, UFSB / Humanities, UFRRJ / Journalism, UNIVERSE / Social Communication, CEFET Celso Suckow da Fonseca RJ or IFRJ / Music, UFF / ADM, SENAC RJ / Photography, ESPM / Communication, UNIRIO / Theater / Sciences, UFF / SSN and PPGC / CEP-FDC-DECEx-DETMil. As the results of the project may be accessible on websites and portals authorized by $\mathrm{CNPq}$, the scope is potentially greater, including the collaborating institution UFSB and other possible locations. Some municipalities of the 85 schools of the FAETEC network will be served, with the suggestion of State Elementary Schools and State Technical Schools of the technical-vocational high-level, with two schools in Campos dos Goytacazes, Marechal Hermes, Niterói, Quintino Bocaiúva, São Cristóvão, Saquarema and Volta Redonda, in addition to about thirteen locations to which the results: teaching Social and Environmental Responsibility Campaigns uniting Bioeconomy and Biocommunication in the project.

\section{Planned Action Actions}

In this sense, we propose actions such as Workshops and other Events and activities cited, dealing with Bioeconomics in the Teaching of Socioenvironmental Responsibility Campaigns in Schools from Elementary to High School / Technical Professionals at FAETEC RJ, that is, Biocommunication covering Demarketing or consumption Consciousness, Reuses and Bioproducts in the face of the Sustainable Economy, in the context of Diversity and Social Wealth Teaching the creation of campaigns and their dissemination on social networks such as Facebook, for example, using cell phones and other mobile devices belonging to leading students for educational purposes.

\subsection{Research Focus and Scope}

This study represents techniques on the economic and citizen empowerment of minorities, especially girls and women interested in Bioeconomy and Biocommunication, scientific areas with sparse historical representativeness; teaching how to generate content and sharing experiences of dissemination and popularization of Human and Social Sciences, aiming at professionalizing practice; in addition to interdisciplinary and transdisciplinary practices in arts, Portuguese, science and digital socioenvironmental communication connecting academic knowledge and practice to artistic, cultural and professional.

\subsection{Expected Dissemination Actions}

In other words, Accessibility to Knowledge can take place via actions such as Open Doors Day with a visit to a Communication and Marketing laboratory agency and 
“internship for 1 day" activity, to access Advertising and Marketing techniques for the each one's job market; the seminar or cliché of lectures / round table with professors from universities and collaborating institutions bringing contents and reflections on the practice in human, social, applied social sciences such as Communication and also the Theater, Sciences and other Languages related to these areas, case of Digital Environmental Communication. The suggested actions aim to popularize social technologies and assistive technologies, at the same time, because more than the Workshops, the other Events intend to be life alternatives that use modern audiovisual and interactive techniques to address the socio-environmental problem of the communities surrounding the 8 units from the FAETEC network proposals for the practice of teaching Bioeconomy and Biocommunication in $\mathrm{RJ}$, as occurs in other Brazilian locations.

\section{Current Affairs and Perspectives}

This study does not intend to anticipate the results of the work proposal for SNCT 2019, as it depends on approval by the CNPq evaluation committee.

It is considered that the practices that unite proposed Bioeconomics and Biocommunication are relevant to the extent that they contribute to the formation of students, generate content and the sharing of experiences of science dissemination and popularization, impacting professional practice, in the sense of uniting theory and practice.

It is important to stimulate new generations, mainly of FAETEC do RJ's elementary and technical-technical education, in addition to university students and other interested publics to generate content and the sharing of science dissemination and popularization experiences, aiming at professionalizing practice. Interdisciplinary and transdisciplinary practices in theater, arts, languages, sciences and digital environmental communication will be promoted, combining academic and artistic knowledge with artistic, cultural and professional activities through the use of audiovisual and digital resources, in the activities developed in the teaching units and at ETEAB / FAETEC.

\section{Conclusion}

In these terms, the proposal aims to popularize social technologies and assistive technologies for teaching Social and Environmental Responsibility campaigns, uniting Bioeconomics and Biocommunication based on Accessibility to Knowledge, with the teaching of techniques for economic empowerment and minority citizens, such as girls and women notably interested in Applied Social Sciences and Sciences such as Social Communication emphasizing New Information and Communication Technologies in the digital age, in scientific areas with little historical representativeness [9].

\section{Acknowledgements}

To colleagues and students of the institutions [such as UNIVERSO, UNIRIO, UFRJ and all the others] collaborating on the proposal to disseminate the teaching of social and environmental responsibility campaigns in FAETEC elementary and high school and technical-professional schools, especially from ETEAB where I teach. To the National Council for Scientific and Technological Development $(\mathrm{CNPq})$ and the organizing committee of the National Week of Science and Technology - SNCT 2019. To the organizing team of the event EIA - Event of Environmental Initiatives Internal and External to UNIRIO, where this article was partially presented and currently reworked.

\section{References}

[1] ARENS, W. F.; SHAEFER, D. H.; WEIGOLD, M. F. Propaganda. Porto Alegre: AMGH, 2013, pp. 19.

[2] CAVALCANTI, C. Em busca da compatibilização entre a ciência da economia e a ecologia: bases da economia ecológica. In: VIEIRA, P. F.; MAIMON, D. [Orgs.]. As ciências sociais e a questão ambiental: rumo à interdisciplinaridade. Rio de Janeiro: APED; Belém: NAEA/UFPA, 1993.

[3] CENSO IBGE 2010. Disponível em: https://censo2010.ibge.gov.br/. Acesso em: 18 de julho de 2019.

[4] CGEE- PANORAMA DA BIOECONOMIA NO BRASIL E IDENTIFICAÇÃO DAS ÁREAS ESTRATÉGICAS. Relatório Final. Brasília, DF: Centro de Gestão e Estudos Estratégicos, $2017 . \quad$ Disponível em https://www.cgee.org.br/documents/10195/734063/2665_Pano rama + da + Bioeconomia + no + Brasil + e + Identifica $\% \mathrm{C} 3 \% \overline{\mathrm{A}} 7 \% \mathrm{C}$ $3 \% \mathrm{~A} 3 \mathrm{o}+$ das + areas + estrategicas.pdf/edef5bb2-2aa8-48dc-800 2-be57cflb688f?version=1.0. Acesso em: 11 de setembro de 2019.

[5] CNI - CONFEDERAÇÃO NACIONAL DA INDÚSTRIA. Bioeconomia: uma agenda para o Brasil. Brasília: CNI, 2013. Disponível http://www.portaldaindustria.com.br/publicacoes/2019/4/bioec onomia-uma-agenda-para-brasil/. Acesso em: 11 de setembro de 2019.

[6] KOTLER, P.; KARTAJAYA, H.; SETIAWAN, I. Marketing 3.0: as forças que estão definindo o novo marketing centrado no ser humano. Rio de Janeiro: Elsevier, 2010.

[7] MCTIC - MINISTÉRIO DA CIÊNCIA, TECNOLOGIA, INOVAÇÕES E COMUNICAÇÕES. Bioeconomia. Disponível em: https://www.mctic.gov.br/mctic/opencms/ciencia/SEPED/Bioe conomia/Bioeconomia.html. Acesso em: 20 de agosto de 2019a. Acesso em: 11 de setembro de 2019.

[8] MCTIC - MINISTÉRIO DA CIÊNCIA, TECNOLOGIA, INOVAÇÕES E COMUNICAÇÕES. Bioeconomia: diversidade e riqueza para o desenvolvimento sustentável. Disponível em: https://snct.mctic.gov.br/semanact/opencms/noticias/arquivos/ 2019/07/12/Bioeconomia-Diversidade-e-Riqueza-para-o-Dese nvolvimento-Sustentavel.html. Acesso em: 18 de setembro de 2019b. Acesso em: 11 de setembro de 2019. 
[9] MCTIC - MINISTÉRIO DA CIÊNCIA, TECNOLOGIA, INOVAÇÕES E COMUNICAÇÕES. Chamada CNPQ/MCTIC-SEPED $n^{\circ}$ 14/2018 Semana Nacional de Ciência e Tecnologia - SNCT 2018. Disponível em: file://C:/Users/Hp/Desktop/Chamada_14_2018.pdf. Acesso em: 11 de novembro de 2018. Acesso em: 11 de setembro de 2019.

[10] PÊCHEUX, Michel. Semântica e discurso: uma crítica à afirmação do óbvio. Campinas: UNICAMP, 1988.

[11] RODRIGUEZ, A. D. Vida, métrica e logos. Tese de Doutorado. Orientada por Rochele de Quadros Loguercio. Universidade Federal do Rio Grande do Sul. Instituto de Ciências Básicas da Saúde. Programa de Pós-Graduação em Educação em Ciências: Química da Vida e Saúde. Porto Alegre: BR-RS, 2016. Disponível

em: https://www.lume.ufrgs.br/bitstream/handle/10183/150200/00 1008295.pdf?sequence $=1$. Acesso em: 5 de agosto de 2019, pp. 69 .
[12] SEN, A. K. Desenvolvimento como liberdade. São Paulo: Companhia das Letras, 2000.

[13] SILVA, M. A. Introdução à economia ecológica: a economia na perspectiva ecológica. Minicurso - $61^{\mathrm{a}}$ Reunião Anual da Sociedade Brasileira para o Progresso da Ciência, Manaus, UFAM, 2009.

[14] SILVA, M. F. de O.; PEREIRA, F. dos S.; MARTINS, J. V. B. A bioeconomia brasileira em números. BNDES Setorial, Rio de Janeiro, n. 47, p. [277]-331, mar., 2018. Disponível em https://web.bndes.gov.br/bib/jspui/bitstream/1408/15383/1/BS 47_Bioeconomia_FECHADO.pdf. Acesso em: 11 de setembro de 2019.

[15] SINOPSES ESTATÍSTICAS DA EDUCAÇÃO BÁSICA INEP 2018. Disponível em: http://inep.gov.br/sinopses-estatisticas-da-educacao-basica. Acesso em: 18 de julho de 2019. 